\title{
Dengue Spatial Distribution and Environment Factor in Banjarnegara District, Central Java Province
}

\author{
Sunaryo $^{1, *}$, Tri Ramadhani ${ }^{1}$, Dyah Widiastuti ${ }^{1}$ \\ ${ }^{1}$ Banjarnegara Health Research and Development Unit, Indonesia \\ "Corresponding author. Email : yok_ban@yahoo.com,
}

\begin{abstract}
Dengue Hemorrhagic Fever (DHF) is caused by dengue virus that is spread through the bite of the Aedes aegypti.spp mosquitoes. Banjarnegara District is a new DHF endemic area in Central Java Province. Insidence Rate in 2018 was 14/1.00.000 population. The larval free rate in Banjarnegara District was less than National rate $(25 \%)$. Efforts to control dengue cases have been carried out including fogging, Sterile Insect Tecnique and larvae control. This study aimed to determine the pattern of dengue cases distribution and environmental spatial risk factors in Banjarnegara District from 2017-2019. A descriptive research using a cross sectional approach was conducted in Juli-August 2019. Spatial analysis was applied using the Geographic Information System (GIS) application with ArcView GIS devices. Cases distribution in Banjarnegara were overlaid with topographic map and population density in each sub district. According to the report of Banjarnegara Public Health Office, there were 144 DHF cases in 2017, 108 cases in 2018 and 884 cases in 2019. The spread of dengue cases were not only in urban areas but also in rural areas. More dominant cases were found in areas below 375 meters above sea level. The closest land use was the irrigated paddy field and the presence of a river flow. Most cases were distributed in areas with population densities of more than 1000-2500 people / km2. Dengue cases were more dominant in lowland areas near paddy fields and densely populated areas. Increased vector and dengue cases surveillance efforts were needed, especially at low-lying areas with community empowerment by installing ovitrap in each house.
\end{abstract}

Keywords: Dengue hemorrhagic fever, distribution, spatial

\section{INTRODUCTION}

Dengue is a mosquito-borne viral disease that has rapidly spread in all regions of WHO in recent years. Dengue virus is transmitted by female mosquitoes mainly of the species Aedes aegypti and, to a lesser extent, Ae. albopictus [1]. Dengue is one of the public health problems in Indonesia where the number of cases is increasing and distribution is expanding [2]. Incidence rate (IR) in Central Java Province during last three years was reported as follows: $43,38 \%$ in $2016,21,6 \%$ in 2017 and $10.02 \%$ in 2018 . Some time ago, DHF only found in urban area, but in this time, DHF can be found in almost all of both urban and rural areas. In 2007, 33 of 35 districts in Central Java are dengue endemic areas, and in 2019 all over the districts were dengue endemic areas with a fairly high number of cases [3]. Banjarnegara District is a new DHF endemic area in Central Java Province. Insidence Rate in 2018 was 14/1.00.000 population [4].

Dengue vector transmiter in Banjarnegara identified of Aedes aegypti and Aedes albopictus. Both of these vectors have been declared transovarial, even Aedes albopictus as a secondary vector found a higher proportion of dengue viruses than Aedes aegypti, but in the population of Aedes aegypti is more dominant in the Banjarnegara District [5, $6]$.

The larval free rate in Banjarnegara District was less than National rate $(25 \%)$. Efforts to control dengue cases have been carried out including fogging, Sterile Insect Tecnique and larvae control [4].

Disease prevention will be much easier whenever the understanding of the diseases including its patterns is understood. An approach to understanding the disease was by mapping the cases according to areas [7].

This study aimed to determine the pattern of distribution of dengue cases and environmental spatial risk factors in Banjarnegara District from 2017-2019. Mapping of dengue cases in Banjarnegara District spatially was performed in order to analyze the spatial risk factors that affect the incidence of dengue in Banjarnegara District using Geographic Information Systems applications and information in the spatial distribution of dengue which include place and time. The results of this study were expected to assist the program in dengue surveillance and control as early precautions of dengue cases. 


\section{METHOD}

The study of the Dengue spatial distribution was done in Banjarnegara, Central Java Province based on dengue cases data from the last 3 year (from 2017 to 2019). A descriptive research using a cross sectional approach was conducted in Juli-August 2019. Spatial analysis was applied using the Geographic Information System (GIS) application with ArcView GIS devices. Stratification village based on dengue cases were divided into: endemic, sporadic and free DHF village. Dengue cases were analyzed based on topographic map, while the analysis based on land use and population density in the case of transactions are carried out only in 2019. Banjarnegara topographic maps obtained from the BIG (Information of Geospatial Unit) with a scale of 1: 25,000. Data processing (data management) includes editing, coding, entry and analysis of data which were then processed using overlaying Arc Gis 10 program [8].

\section{RESULTS AND DISCUSSION}

Banjarnegara is one of the District in Central Java Province, located $109.703527^{\circ}$ East Longitude and $7.385171^{\circ}$ South Latitude. Banjarnegara is consisted of 20 sub-districts with 106.970,997 ha.

\section{Situation of Dengue in Banjarnegara}

According to the report of Banjarnegara Public Health Office, there were 144 Dengue cases in 2017,108 cases in 2018 and 884 cases in 2019. The spread of dengue cases were not only occured in urban areas but also in rural areas.
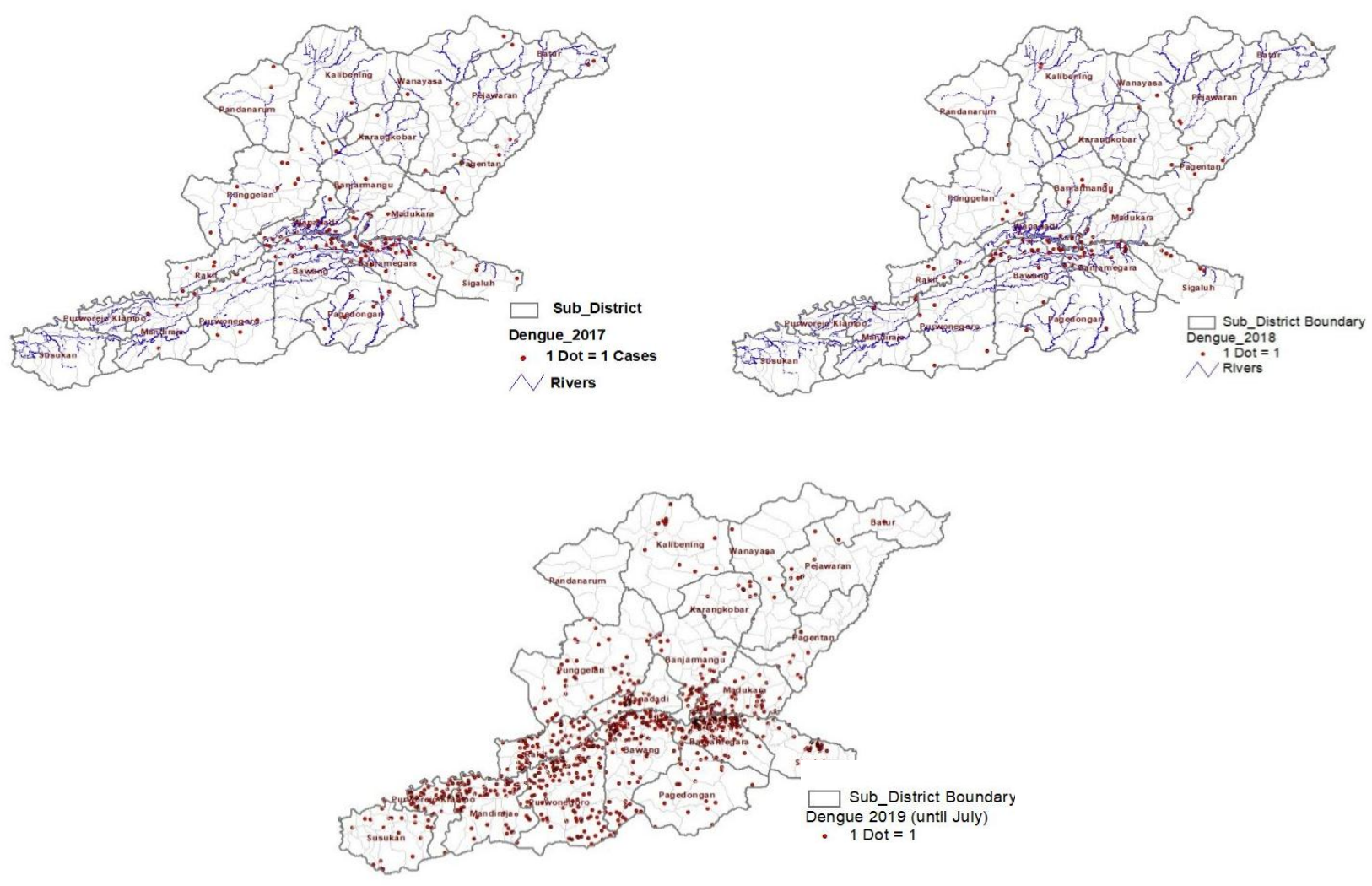

Figure 1. Distribution of Dengue Infection in Banjarnegara during 2017 - 2019

Figure 1. showed that the increasing number of dengue infection cases in Banjarnegara during 2017 -2019 were clustered in some subdistrict such us Kutabanjarnegara, Bawang. 


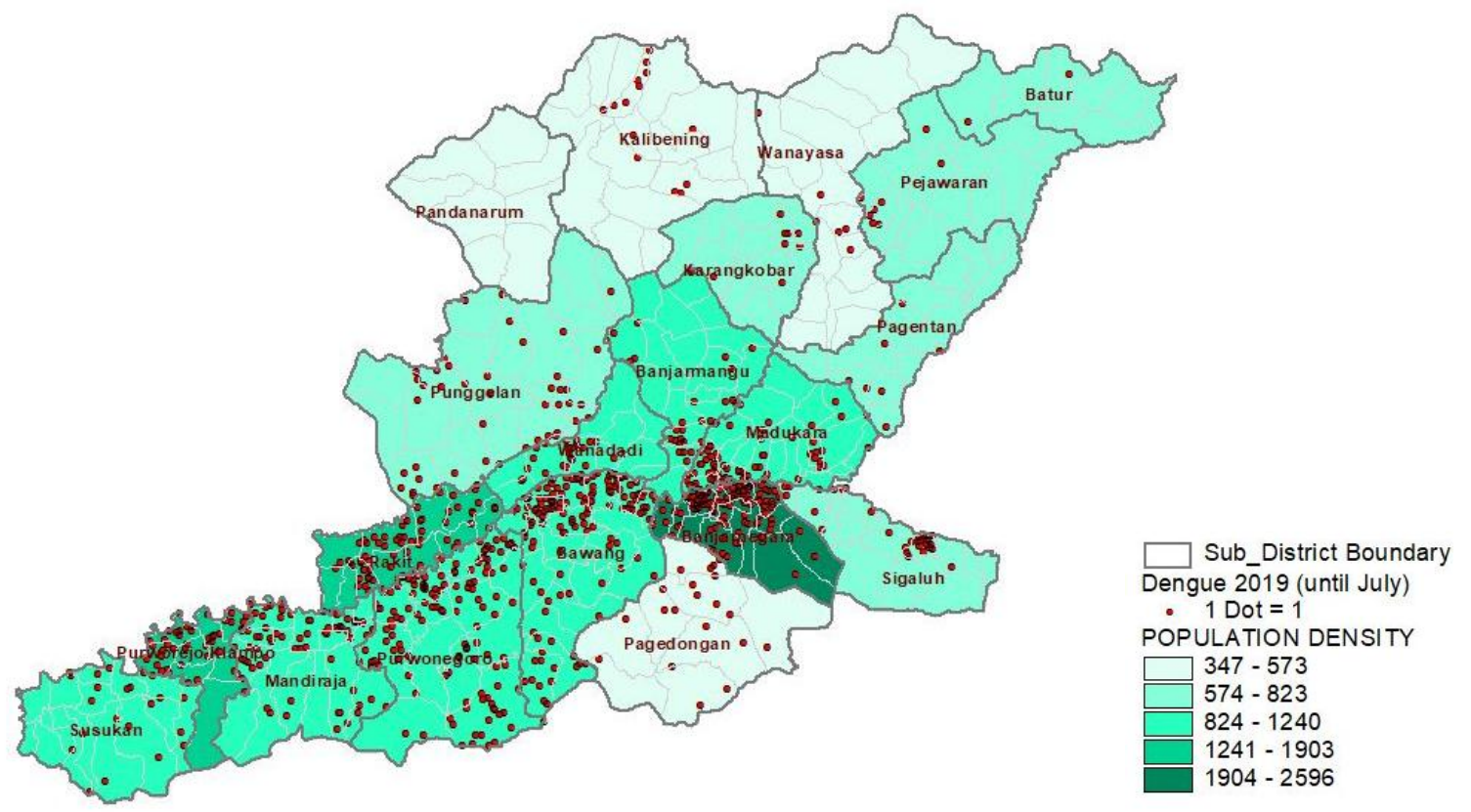

Figure 2. Distribution of dengue and population density in Banjarnegara district

Figure 2 showed that most cases were distributed in areas with population densities more than 1000-2500 people / km2.

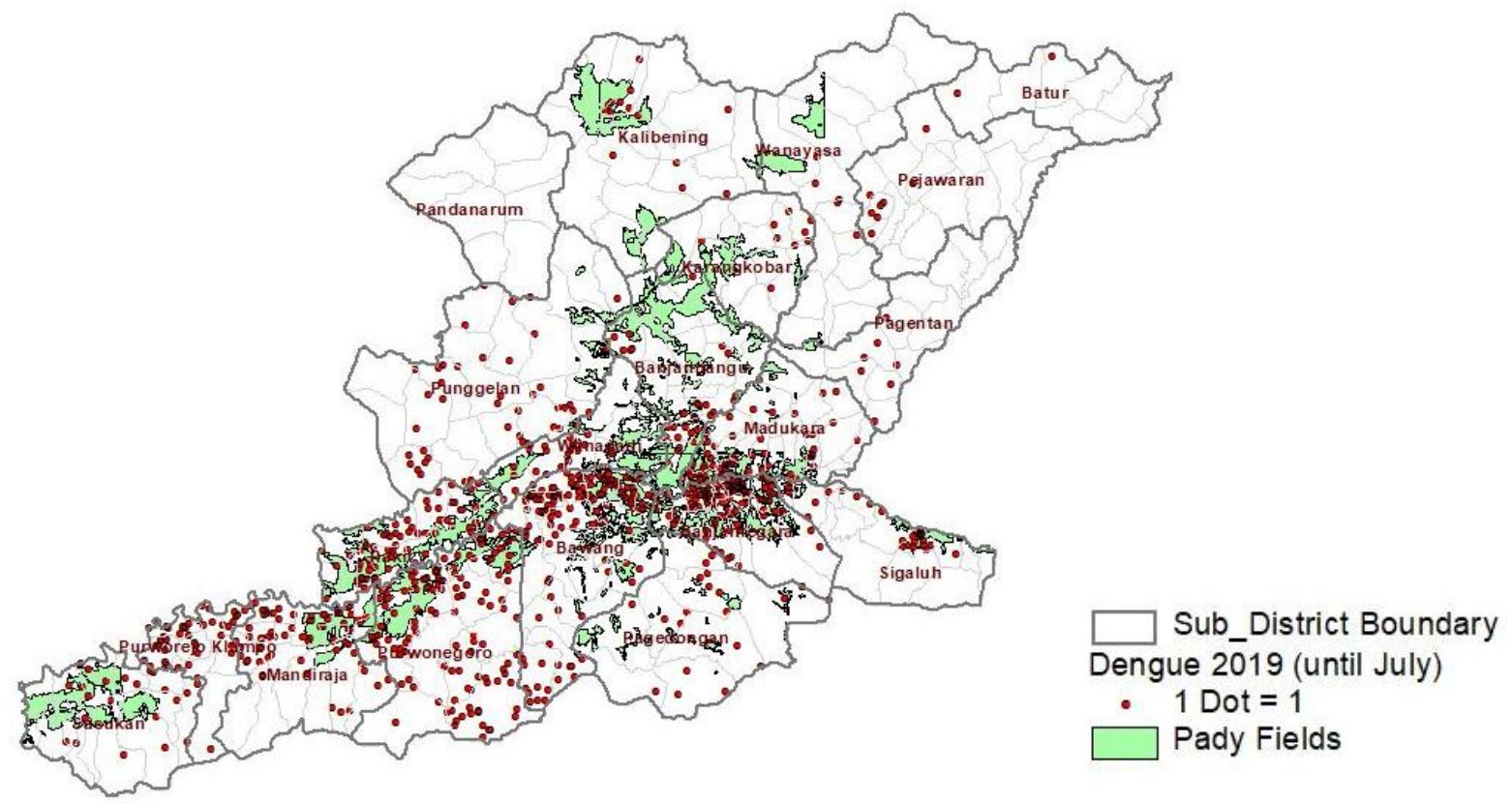

Figure 3. Distribution of Dengue Infection cases overlaid with land-use in Banjarnegara in 2019

Figure 3 showed that dengue infection cases mostly found around the river and rice field areas. 


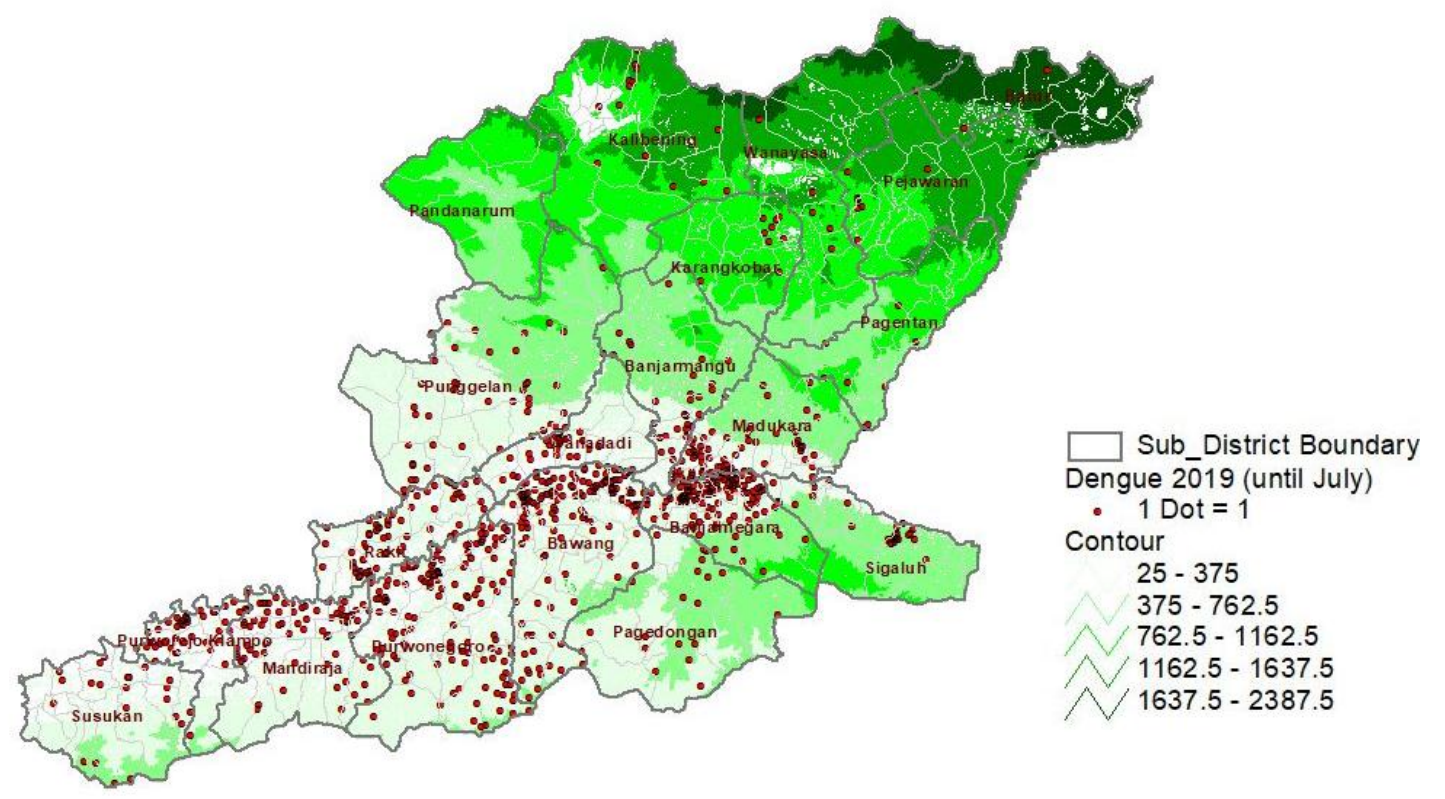

Figure 4. Distribution of Dengue Infection cases overlaid topography contour in Banjarnegara in 2019

Figure 4 Showed That Dengue Infection Cases In Banjarnegara Mostly Found In Low-Land Areas. However The Cases Can Be Found In Areas With Altitude Up To 11625 M.

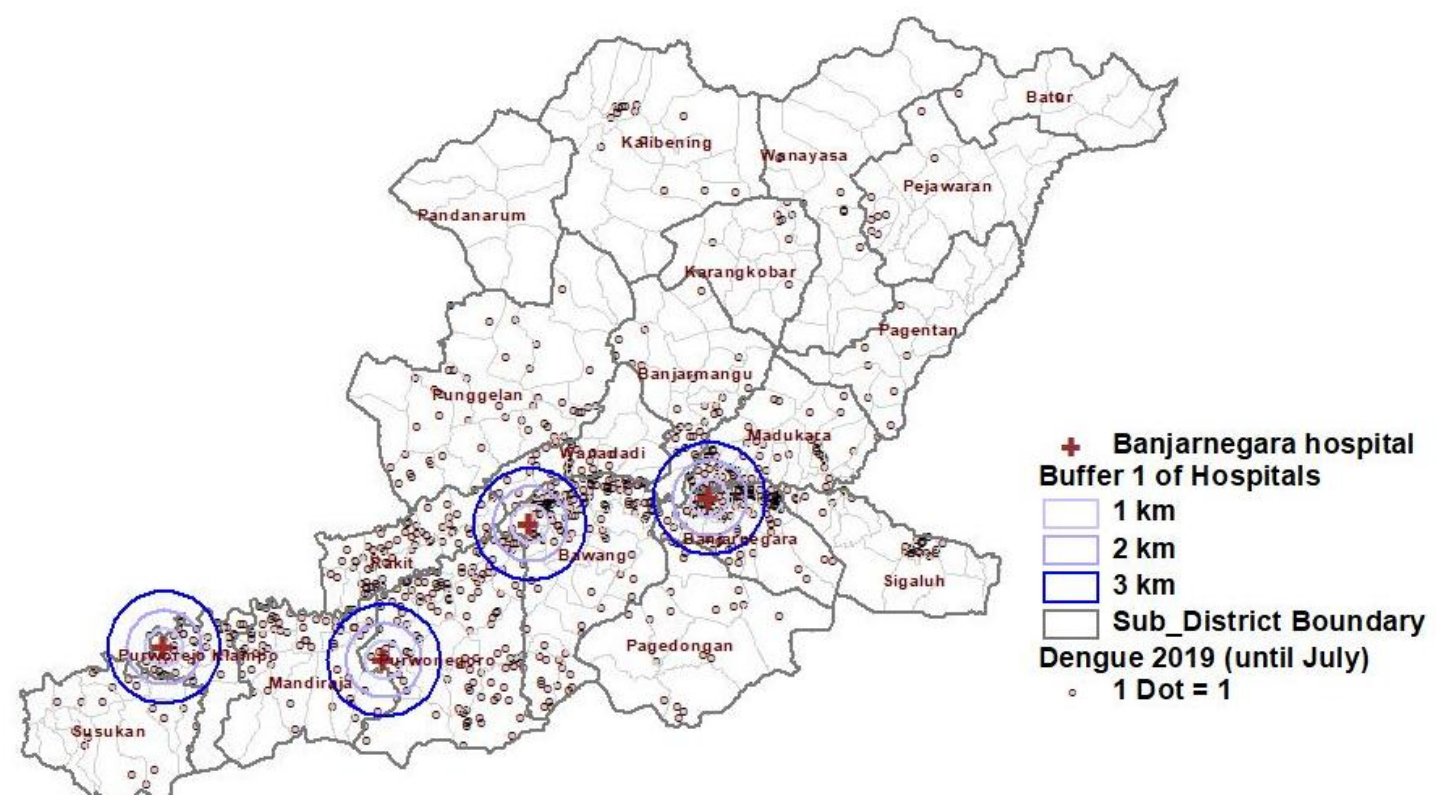

Figure 5. Distribution of Dengue Infection cases overlaid with accession of health facility in Banjarnegara in 2019.

Figure 5 showed that Dengue infection cases mostly found in areas which is closed to health facility. 


\section{DISCUSSION}

Incidence rate of Dengue Fever in Banjarnegara the last three years showed a saw tooth pattern. Distribution of cases was concentrated in urban areas with dense populations such as Kutabanjarrnegara and surrounding area. The distribution pattern of cases were clustered, indicate the concentrated vector habitat, thus potentially greater local transmission [7].

Mapping of dengue case series can be used to examine the dynamics of dengue transmission. This serial map can also be used to assess whether disease patterns are consistent over time in the district concerned. If it turns out to be consistent, this shows that dengue prevention activities are focused on areas with higher risk. This mapping also helps the Health Office identify the focus of dengue transmission, as well as to assess the effectiveness of prevention programs [9].

In general, DHF cases clustering tend to follow the number of population density. The results showed that the dengue cases are more common in urban areas and buffer zones in line with other studies conducted in the Guangzhou region of China that one of the major cities in China and the city of Conghua and Zengcheng buffer that DHF is more common [10].

Based on altitude levels, all of dengue cases are found in the lowlands, with a height of 25-375 meters above sea level. Most of the areas in Banjarnegara have dengue cases and only about a quarter of it which is the area with an altitude of over 200 meters above sea level without any dengue cases, due to these areas were dominantly covered by forest. Most of low land areas with dengue cases were pady field. Research in Phitsanulok, Thailand also concluded that housing in the pady fields have a major role in the growth of dengue vectors [11]. Most of Dengue cases were served in the General Hospital $\mathrm{Hj}$. Anna Lasmanah Banjarnegara. These cases were distributed within distance of $3 \mathrm{~km}$ around General Hospital. Hj. Anna Lasmanah Banjarnegara general hospital. the area with the most dengue cases is found closest distance. According Antonio, distance to service centers and travel time has a significant impact with health problems and utilization of health care facilities [12, 13]. Local Government should conduct the curative and preventive effort to control dengue in order to reduce the number of deaths due to DHF, and also prevent nosocomial transmission that may occur in the environment hospital.

\section{CONCLUSION}

Dengue cases were more dominant in lowland areas near paddy fields and densely populated areas. Increased vector and dengue cases surveillance efforts was needed, especially at low-lying areas with community empowerment by installing ovitrap in each house.

\section{ACKNOWLEDGMENT}

We would like to thank the Head of Banjarnegara District Health officer, and Banjarnegara Health Research and Develompent Unit, for guidance and direction of the researchers and thanks to entomology technicians for helping us during the research. We also wish to thank all the participants who contributed to this study.

\section{REFERENCES}

[1] WHO, Dengue And Severe Dengue, 2019 Available At: $\quad$ Https://Www.Who.Int/News-Room/FactSheets/Detail/Dengue-And-Severe-Dengue

[2] Pusat Data Dan Informasi, Kementerian Kesehatan RI. Situasi Demam Berdarah Dengue Di Indonesia. Jakarta: Pusdatin Kemenkes RI; 2017.

[3] Provincial Health Officer, 2018 Health Profile Of Central Java Province

[4] Banjarnegara Health Profile, 2018 Banjarnegara District Helath Officer

[5] Nova P, Dengue Vector Distribution In Urban And Ryral Areas Ini Banjarnegara District, 2013 Balaba Vol 41.

[6] Dyah W, Agung P, Nova P, Indeks Entomologi Dan Transmisi Transovari Yang Mendukung Peningkatan Kasus Demam Berdarah Di Kabupaten Banjarnegara, SPIRAKEL, Vol. 8 No 1. Juni 2016:30-37.

[7] Respati T, Spatial Distribution Of Dengue Hemorrhagic Fever (DHF) In Urban Setting Of Bandung City, Global Medical And Health Communication; 2017;5(3):212-8

[8] Danudoro P (1996). Digital Image Processing; Pengolahan Citra Digital; Theory And Its Application In Remote Sensing. Faculty Of Geography. Gadjah Mada University. Yogyakarta. Indonesian

[9] Sunaryo, Geographic Information System For Public Health, Yogyakarta Diandra Offset, 2018

[10] Liu C, Qiyong Liu, Hua Liang Lin, Benqiang Xin, Jun Nie (2013). Spatial Analysis Of Dengue Fever In Guang Dong Province, China 2001-2006. Asia - Pacific Journal Of Public Health XX(X) 1-9@ 2013 APJPH Reprints And Permission:Sagepub.Com/Journals Permissions.Nav DOI: 10.1177/1010539512472356.

[11] Sarfras MS, Nitin KT, Taravudh T, Thawisak T, Pornsuk K, Marc S (2012). Analyzing The SpatioTemporal Relationship Between Dengue Vector Larval Density And Landuse Using Factor Analysis And Spatial Ring Mapping.

[12] Hotnida Sitorus, Lasbudi (2014). Accessibility Of Health Care Facilities In Bangka Belitung Province. Balai Litbangkes Baturaja Available 
At:Http://Ejournal.Litbang.Depkes.Go.Id/Index.P Hp/Spirakel/Article/Download/

[13] Antonio D L, Pedro Cabral Geographic Accessibility To Primary Helathcare Center In Mozambique, Int J Equity Health. 2016; 15: 173. Published Online 2016 Oct 18. Doi: $10.1186 /$ S12939-016-0455-0 